Original article

\title{
Contamination of vegetable products with nitrates as a public health risk factor
}

\author{
Olga G. Bogdanova ${ }^{1}$, Natalia V. Efimova ${ }^{1}$, Inna Yu. Tarmaeva ${ }^{2}$ \\ ${ }^{1}$ East-Siberian Institute of Medical and Ecological Research, Angarsk, Russia \\ ${ }^{2}$ Federal Research Centre of Nutrition and Biotechnology, Moscow, Russia
}

Received 25 January 2021, Revised 24 May 2021, Accepted 26 July 2021

(C) 2021, Russian Open Medical Journal

\begin{abstract}
Our study aimed to investigate the contamination levels of vegetable products with nitrates and to evaluate the associated health risks to population of Baikalia.

Materials and Methods - The characterization of VP contamination with nitrates is based on the data of the Federal Information Foundation for Public Hygiene Monitoring in the Russian Federation for 2015-2019. The computation of hazard ratios was conducted sensu the Guidelines 2.1.10.1920-04 'Human Health Risk Assessment Caused by Environmental Pollutants'.

Results - The proportion of VP samples with augmented nitrate content in the Republic of Buryatia was 4.5 times higher than in Irkutsk Oblast. At the same time, nitrate concentrations did not differ significantly: in the Republic of Buryatia, median concentration was 164.24 (158.52-169.95) $\mathrm{mg} / \mathrm{kg}$, and 90th percentile was 940.76 (868.49-1013.03) $\mathrm{mg} / \mathrm{kg}$; in Irkutsk Oblast, corresponding amounts were 169.1 (158.55-177.55) and $978.0(927.3-1028.7) \mathrm{mg} / \mathrm{kg}(p>0.05)$. The alimentary effect of nitrates on the child population in Republic of Buryatia led to unacceptable risk ( $\mathrm{HQ}>1.0$ at the level of the average centile trend).

Conclusion - The results of conducted analysis confirmed the need to carry out dynamic studies of child health indicators due to the impact of nitrates in the municipalities of the cluster 1 in the course of the public hygiene monitoring (with child health as a mandatory component of the latter) for developing further predictive indicators.
\end{abstract}

Keywords: vegetable products, risk assessment, nitrate contamination.

Cite as Bogdanova OG, Efimova NV, Tarmaeva IYu. Contamination of vegetable products with nitrates as a public health risk factor. Russian Open Medical Journal 2021; 10: e0404.

Correspondence to Olga G. Bogdanova. Address: East-Siberian Institute of Medical and Ecological Research, 12A Residential District No. 3, Angarsk 665826, Russia. Phon.: +7 (395) 558 6910. E-mail: olga.bogdanova2001@gmail.com.

\section{Introduction}

The increasing role of global challenges caused by food quality and safety, characterized by contamination with chemical agents resulting in increased health risks for population of various age categories and social statuses is supported by the data from domestic and foreign published sources [1-7]. At the same time, the development of publicly available information databases on quality and safety of produce and produce-based foods, and on the risks associated with them, relate to the strategy of creating the risk analysis methodology $[1,3]$. According to the data provided by the Federal Information Foundation for Public Hygiene Monitoring in the Russian Federation, nitrates were the leading pollutant over recent years. The proportion of samples of the vegetable products (hereinafter, VP) with contaminants exceeding the hygienic standards ranged $1.09-2.31 \%$ [8-9]. Results of numerous publications, including those by Lin Y.J., et al., implied an absence of significant risks from the effects of nitrates and nitrites in vegetables for most population groups, but at the same time, preschoolers constitute a very sensitive group [10-12]. Despite a large number of studies on the problems of VP quality and safety, there are still limited data on the formation of health risks for the population of Siberian regions caused by the influence of foods and produce contaminated with nitrates $[13,14]$. Such comparative study identifying territories and risk groups for the development of preventive recommendations is of substantial interest. The objective of our study was to investigate the levels of vegetable products' contamination with nitrates and to assess associated health risks to both adult and child populations of the Baikalia.

\section{Material and Methods}

\section{Information sources}

Information on VP contamination was obtained from the regional chapter of the Federal Information Foundation for Public Hygiene Monitoring in the Republic of Buryatia and federal budgetary health institutions: Center for Hygiene and Epidemiology in Republic of Buryatia and Center for Hygiene and Epidemiology in Irkutsk Oblast. The results of 2015-2019 studies from laboratory test protocols of 11,037 VP samples were copied, including 5,003 test results in Republic of Buryatia and 6,034 in Irkutsk Oblast. Samples of VP were taken as part of public hygiene monitoring, control and supervision measures and production control. The determination of nitrate content was carried out via ion-specific electrode method in accordance with the guidelines 5048-89 'Methodological Guidelines for Determination of Nitrates 
and Nitrites in Crop Production'. The lower limit of nitrate detection was $6 \mathrm{mg}$ per $\mathrm{dm}^{3}$ of the analyzed solution, the limit of reliable determination of nitrates in the analyzed sample was 30 $\mathrm{ppm}(\mathrm{mg} / \mathrm{kg})$. The determination range of nitrates was 50.0-3000.0 $\mathrm{mg} / \mathrm{kg}$, with the error of $+/-0.25 \mathrm{mg} / \mathrm{kg}$ from the average result.

\section{Risk assessment}

The computation of hazard ratios was conducted sensu the Guidelines 2.1.10.1920-04 'Human Health Risk Assessment Caused by Environmental Pollutants' and Methodological Guidelines 2.3.7.2519-09 'Determining the Exposure and Assessing the Risk of Population Exposure to Chemical Contaminants in Food Products' using the formula:

$$
\begin{aligned}
& \mathrm{HQ}=\mathrm{AD} / \mathrm{RfD} \text {, where } \\
& \mathrm{HQ} \text { - hazard quotient; } \\
& \mathrm{AD} \text { - average dose, } \mathrm{mg} / \mathrm{kg} ; \\
& \mathrm{RfD} \text { - reference (safe) dose, } \mathrm{mg} / \mathrm{kg} \text {. }
\end{aligned}
$$

Nitrate content is presented as mean values and their $95 \%$ confidence intervals $(\mathrm{Cl})$. Consumption parameters were taken in accordance with the average per capita food consumption by the population in Republic of Buryatia on the basis of the data from the Federal Statistics Service (regional chapter in Republic of Buryatia). The average consumption of each VP and produce per person per year was calculated. Average weights of an adult and a child were assumed at the levels of $70 \mathrm{~kg}$ and $15 \mathrm{~kg}$, respectively. Average daily doses were calculated based on the sample average of nitrates in consumed produce and VP. Reference exposure levels (reference doses) were used to calculate non-carcinogenic risks. Non-carcinogenic health risks from chemical pollutants were assessed by hazard quotients (HQ) based on the chronic daily intake of nitrates with VP and produce.

\section{Statistical data processing}

Statistical processing of study results was conducted using Statistica 10.0 software. To assess the normality of quantitative data prior to the analysis, the Kolmogorov-Smirnov's criterion was employed. For quantitative variables, we calculated arithmetic mean, its standard deviation and error, median, 90th percentile; qualitative data were assessed by specific weights and errors. $\mathrm{K}$ means clustering was used to identify high-risk areas. The ranking of the administrative territories in Republic of Buryatia was carried out using double clustering. Five-year data for 22 territories were grouped into clusters based on the average annual values of nitrates in VP in order to identify risk areas. Ward's minimum variance method was used to determine the number of clusters that grouped together the territories with maximum similarity index. It was established that the optimal number of clusters was 3. The K-means clustering was carried out to group similar territories and analyze them on classified indicators. In all studies, differences at 95 percent probability $(p<0.05)$ were presumed statistically significant.

\section{Results}

We discovered that over the period of 2015-2019, despite the geographical proximity of two Baikalia regions (Republic of Buryatia and Irkutsk Oblast), nitrate contamination of VP in each of them was quite different. With a larger number of tested VP samples in Irkutsk Oblast - 1206.8 (1097.3-1316.3) vs. the number of tested samples in Republic of Buryatia - 1000.6 (887.4-1113.8), the specific weight of VP that did not meet the mandatory requirements for nitrate content in the Irkutsk Oblast was 4.3 times lower: $1.04(0.80 ; 1.28)$ vs. $4.51(4.11 ; 4.91)$ in Buryatia. Nitrate concentrations in VP samples were: in Republic of Buryatia, the median was $164.24(158.52-169.95) \mathrm{mg} / \mathrm{kg}$ and the 90th percentile was $940.76(868.49-1013.03) \mathrm{mg} / \mathrm{kg}$; in Irkutsk Oblast they were 169.1 (158.55-177.55) and $978.0(927.3-1028.7) \mathrm{mg} / \mathrm{kg}$, respectively, and the differences did not have statistical significance $(p>0.05)$. Taking into account the frequency of VP detection that did not meet hygienic requirements for nitrate

\begin{tabular}{|c|c|c|c|c|c|c|}
\hline \multirow{2}{*}{$\begin{array}{l}\text { Cluster } \\
\text { number }\end{array}$} & \multirow{2}{*}{ Municipalities } & \multicolumn{3}{|c|}{ Nitrate content, $\mathrm{mg} / \mathrm{kg}$} & \multicolumn{2}{|c|}{ Number of observations per cluster } \\
\hline & & Mean & Minimum & Maximum & Absolute number & $\%$ \\
\hline 1 & Kyakhta, Tarbagatay, Ulan-Ude & 281.34 & 25.60 & 2321.92 & 3 & 13.62 \\
\hline 2 & $\begin{array}{l}\text { Severobaikalsk, Mukhorshibir, Zaigraevo, Tunkinsky District, Khorinsk, Kabansk, } \\
\text { Dzhidinsky District }\end{array}$ & 179.03 & 32.85 & 1451.84 & 7 & 31.84 \\
\hline 3 & $\begin{array}{l}\text { Pribaykalsky District, Zakamensk, Yeravninsky District, Ivolginsk, Bauntovsky District, } \\
\text { Barguzin, Selenginsk, Kurumkan, Okinsky District, Muysky District, Bichura, Kizhinga }\end{array}$ & 126.33 & 64.67 & 315.36 & 12 & 54.54 \\
\hline
\end{tabular}
content, further studies are aimed at identifying key points of risk management in Republic of Buryatia.

\begin{tabular}{|c|c|c|c|c|c|}
\hline \multirow{2}{*}{ Product group } & \multicolumn{2}{|c|}{ I (average daily intake of nitrates, $\mathrm{mg} / \mathrm{kg}$ per day) } & \multirow{2}{*}{ Product consumption, $\mathrm{kg} /$ day } & \multicolumn{2}{|l|}{$H Q$} \\
\hline & Average centile trend & 90th percentile & & Average centile trend & 90th percentile \\
\hline \multicolumn{6}{|c|}{ Adult/child population (total) } \\
\hline Potatoes & $0.32 / 1.50$ & $0.47 / 2.19$ & 0.18 & $0.20 / 0.94$ & $0.29 / 1.37$ \\
\hline Vegetables and melons & $0.74 / 3.44$ & $1.82 / 2.14$ & 0.21 & $0.46 / 2.15$ & $1.14 / 5.31$ \\
\hline Total vegetable products & $1.06 / 4.94$ & $2.29 / 4.33$ & 0.52 & $0.66 / 3.09$ & $1.43 / 6.68$ \\
\hline \multicolumn{6}{|c|}{ Adult/child population of urban areas } \\
\hline Potatoes & $0.34 / 1.58$ & $0.50 / 2.31$ & 0.19 & $0.21 / 0.99$ & $0.31 / 1.44$ \\
\hline Vegetables and melons & $0.88 / 4.10$ & $2.17 / 10.12$ & 0.25 & $0.55 / 2.56$ & $1.35 / 6.32$ \\
\hline Total vegetable products & $1.22 / 5.68$ & $2.67 / 12.43$ & 0.60 & $0.76 / 3.55$ & $1.66 / 7.76$ \\
\hline \multicolumn{6}{|c|}{ Adult/child population of rural areas } \\
\hline Potatoes & $0.30 / 1.49$ & $0.44 / 2.07$ & 0.17 & $0.19 / 0.93$ & $0.28 / 1.29$ \\
\hline Vegetables and melons & $0.53 / 2.46$ & $1.30 / 6.07$ & 0.15 & $0.33 / 1.54$ & $0.81 / 3.79$ \\
\hline Total vegetable products & $0.83 / 3.95$ & $1.74 / 8.14$ & 0.40 & $0.52 / 2.47$ & $1.09 / 5.08$ \\
\hline
\end{tabular}

Table 1. Characterization of clusters by the nitrate content in vegetables products

Table 2. Hazard coefficients based on the intake of nitrates from vegetables products in the Republic of Buryatia 
In the course of K-means clustering, three groups of administrative municipalities in Republic of Buryatia were identified, differing in nitrate content (Table 1). So, the cluster 1 included Kyakhta, Tarbagatay and the city of Ulan-Ude, which amounted to $13.62 \%$ of the territories; cluster 2 encompassed $38.84 \%$ of municipalities (Severobaikalsk, Mukhorshibir, Zaigraevo, Tunkinsky District, Khorinsk, Kabansk and Dzhidinsky District), other $54.54 \%$ were the part of the cluster 3. The Euclidean distance reached the maximum between the clusters 1 and 3 ( $d=1.124)$, the distances between the No.1 and 2, and No.2 and 3 were close $(0,588$ and 0,569 , respectively).

A comparison of the results showed that $\mathrm{HQ}$, due to nitrate input with VP at the level of the average centile trend, exceeded the permissible level for the child population (Table 2), including in the VP groups total vegetable products (3.09), vegetables and melons $(2.15)$ - in the urban ( 3.55 and 2.56 respectively) and rural population (2.47 and 1.54 , correspondingly).

\section{Discussion}

In the studied municipalities, the priority contaminants (based on the proportion of product samples exceeding hygienic standards for the content of chemical pollutants) were nitrates. Many researchers, including Kalaycıoğlu Z. and Erim F.B., convincingly showed that nitrate concentration in vegetables changed in the following order: leaf $>$ stem $>$ root $>$ inflorescence $>$ fruit $>$ grain $[10,15-18]$. In Baikalia region samples, taken from major VPs, the nitrate content was, on average, $268 \pm 45.2 \mathrm{mg} / \mathrm{kg}$ in cabbage and $84 \pm 11.6 \mathrm{mg} / \mathrm{kg}$ in potatoes. The diet of Baikalia residents differs significantly from food preferences of the population in the southern regions of the Russian Federation [3, $13,14]$ and other countries $[10,19,20]$. Therefore, chemical and analytical research focuses on the VP types commonly used by the local population. Our studies have established that in early cabbage and zucchini (mainly imported produce), nitrate content was the highest. Considerable accumulation of nitrates was also noted in such local produce as beets, late cabbage, late and early carrots, and potatoes.

Analyzing the distribution of individual municipalities in Republic of Buryatia by clusters and the results of the HQ assessment, we could detect some general characteristics, which could cause an emergence of VP that does not meet hygienic requirements for chemical safety. The municipalities included in cluster 1 , in which the highest VP contamination with nitrates was observed, were characterized by unsatisfactory supply of local produce VP and a large volume of imported produce. Cluster 2, mainly represented by southern regions with agricultural orientation, had relatively high provisoning of their own produce. Nitrate contamination of VP in these municipalities (Severobaikalsk, Mukhorshibirsk, Zaigraevo, Tunkinsky, District Khorinsk, Kabansk and Dzhidinsky District) was two times lower than in the 1st cluster. The smallest content of nitrates was found in VP samples from municipalities of the 3rd cluster.

It should be emphasized that $\mathrm{HQ}$ value in terms of nitrate content in the course of VP consumption by the child population exceeded the permissible level $(\mathrm{HQ}>1)$ in all municipalities of the Republic of Buryatia, and ranged 1.64 to 6.49 at an average centile trend and 1.83 to 8.65 at the boundary of the $95 \%$ confidence interval, which indicated an unacceptable risk of non-carcinogenic effects. Currently, the prevailing view is that VP cannot cause nitrate poisoning both in adults $[19,21]$ and in children $[10,22]$.
The leading cause of developing methemoglobinemia in infants includes nitrate contamination of drinking water at a level higher than $10 \mathrm{mg} / \mathrm{l}$ [23], which determines the need for our further research within the risk areas.

\section{Conclusion}

Thus, in the territory of the Baikalia, individual municipalities of the Republic of Buryatia should be considered at risk for the effects of nitrates coming from VP. The alimentary effect of nitrates on the adult population of the Republic of Buryatia, coming from VP, is evaluated as acceptable at the level of the average centile content of the contaminant $(H Q<1.0)$, and as unfavorable at the level of the 90th centile (HQ>1.0), which corresponds to the maximum permissible risk and requires systematic monitoring and control of the nitrate content. In children, nitrate exposure leads to unacceptable risk ( $\mathrm{HQ}>1.0$ at the average centile trend). The results of conducted analysis confirm the need to carry out the dynamic studies of child health indicators due to the effect of nitrates - for children living in the municipalities of the cluster 1 . Hence, public hygiene monitoring of child health should be a mandatory component of future studies and the basis for developing further predicative indicators.

\section{Conflict of interest}

We declare that we have no conflicts of interest.

\section{Ethical approva}

This article does not cover any studies with human participants or animals performed by the authors.

\section{References}

1. Popova AYu. Risk analysis as a strategic sphere in providing food products safety. Health Risk Analysis 2018; (4): 4-12. Russian. https://doi.org/10.21668/health.risk/2018.4.01.

2. Tutelyan VA. To the 90th anniversary of the Institute of Nutrition: a look through the years. Problems of Nutrition 2020; 89(4): 8-23. Russian. https://doi.org/10.24411/0042-8833-2020-10038.

3. Shur PZ, Zaitseva NV, Khotimchenko SA, Fedorenko EV, Sychik SI, Fokin $V A$, et al. On the issue of establishing acceptable daily intake of chemical substancesin food products according to health risk criteria. Hygiene and Sanitation. 2019; 98(2): 189-195. Russian. http://doi.org/10.18821/0016-9900-2019-98-2-189-195.

4. Larionova TK, Bakirov AB, Daukaev RA. Nutritional assessment of adult population in the Republic of Bashkortostan. Problems of Nutrition 2018; 87(5): 37-42. Russian. http://doi.org/10.24411/0042-8833-201810051.

5. Sazonova OV, Gorbachev DO, Nurdina MS, Kupaev VI, Borodina LM, Gavryushin MYu, et al. Hygienic characteristics of actual nutrition of the working population in Samara Region. Problems of Nutrition 2018; 87(4): 32-38. Russian. http://doi.org/10.24411/0042-8833-201810039.

6. Ter Borg S, Verlaan S, Mijnarends DM, Schols JMGA, de Groot LCPGM, Luiking YC. Macronutrient intake and inadequacies of communitydwelling older adults, a systematic review. Ann Nutr Metab 2015; 66(4): 242-255. https://doi.org/10.1159/000435862.

7. Rather I., Koh WY, Paek WK, Lim J. The sources of chemical contaminants in food and their health implications. Front Pharmacol 2017; 8: 830. https://doi.org/10.3389/fphar.2017.00830.

8. Pereira JL, Castro MA, Hopkins S, Gugger C, Fisberg RM, Fisberg M. Prevalence of consumption and nutritional content of breakfast meal among adolescents from the Brazilian National Dietary Survey. J 
$\begin{array}{lllll}\text { Pediatr } & \text { (Rio J) } & \text { 2018; } & \text { 94(6): }\end{array}$ https://doi.org/10.1016/j.jped.2017.10.004.

9. Fung $\mathrm{F}$, Wang HS, Menon S. Food safety in the 21st century. Biomed $\mathrm{J}$ 2018; 41(2): 88-95. https://doi.org/10.1016/j.bj.2018.03.003.

10. Gizaw Z. Public health risks related to food safety issues in the food market: A systematic literature review. Environ Health Prev Med 2019; 24(1): 68. https://doi.org/10.1186/s12199-019-0825-5.

11. Thompson LA, Darwish WS. Environmental chemical contaminants in food: Review of a global problem. J Toxicol 2019; 2019: 2345283. https://doi.org/10.1155/2019/2345283.

12. Poma G, Yin S, Tang B, Fujii $Y$, Cuykx M, Covaci A. Occurrence of selected organic contaminants in edible insects and assessment of their chemical safety. Environ Health Perspect 2019; 127(12): 127009. https://doi.org/10.1289/ehp5782.

13. Litvinova OS. Food safety in the Russian Federation. Retrospective analysis, the prospects of control. Public Health and Life Environment 2016; $\quad(10(283)): \quad 32-35 . \quad$ Russian. https://www.elibrary.ru/item.asp?id=27163092.

14. Saldan IP, Shved OI, Balandovich BA, Nagornyak AS, Mazko ON, Makarova OG, et al. Assessment of risks caused by impacts exerted on a human body by nitrates contained in food products. Health Risk Analysis 2018; $\quad$ (2): $\quad$ 81-88. https://doi.org/10.21668/health.risk/2018.4.09.eng.

15. Lin YJ, Cheng CJ, Chen JW, Lin Z. Incorporating exogenous and endogenous exposures into dietary risk assessment of nitrates and nitrites in vegetables: A probabilistic integrated toxicokinetic modeling approach. J Agric Food Chem 2020; 68(4): 1079-1090. https://doi.org/10.1021/acs.jafc.9b06720.

16. Karwowska $M$, Kononiuk A. Nitrates/nitrites in food - risk for nitrosative stress and benefits. Antioxidants (Basel) 2020; 9(3): 241. https://doi.org/10.3390/antiox9030241.

17. Merino L, Darnerud PO, Toldrá F, Ilbäck NG. Time-dependent depletion of nitrite in pork/beef and chicken meat products and its effect on nitrite intake estimation. Food Addit Contam Part A Chem Anal Control Expo Risk Assess 2016; 33(2): 186-192. https://doi.org/10.1080/19440049.2015.1125530.

18. Vasilovskii AM, Kurkatov SV. Hygienic assessment of food products in Krasnoyrsk region. Vopr Pitan 2012; 81(2): 46-50. Russian. https://pubmed.ncbi.nlm.nih.gov/22774478/.

19. Tarmaeva IYu, Efimova NV, Baglushkina SYu, Belykch Al. Contamination of food raw materials and foodstuffs in irkutsk region. Public Health and Life Environment 2017; (10(295)): 43-45. Russian. https://www.elibrary.ru/item. asp?id=30516911.

20. Hmelak Gorenjak A., Cencič A. Nitrate in vegetables and their impact on human health. A review. Acta Alimentaria 2013; 42(2): 158-172. https://doi.org/10.1556/aalim.42.2013.2.4.

21. Salehzadeh H, Maleki A, Rezaee R, Shahmoradi B, Ponnet K. The nitrate content of fresh and cooked vegetables and their healthrelated risks. PLoS One 2020; 15(1): e0227551. https://doi.org/10.1371/journal.pone.0227551.

22. Williams GM, Aardema M, Acquavella J, Berry SC, Brusick D, Burns $\mathrm{MM}$, et al. A review of the carcinogenic potential of glyphosate by four independent expert panels and comparison to the IARC assessment. Crit Rev Toxicol 2016; 46(sup1): 3-20. https://doi.org/10.1080/10408444.2016.1214677.

23. Kalaycıoğlu Z, Erim FB. Nitrate and nitrites in foods: Worldwide regional distribution in view of their risks and benefits. J Agric Food Chem 2019; 67(26): 7205-7222. https://doi.org/10.1021/acs.jafc.9b01194.

24. Wikoff D, Thompson C, Rager J, Chappell G, Fitch S, Doepker C. Benefitrisk analysis for foods (BRAFO): Evaluation of exposure to dietary nitrates. Food Chem. Toxicol 2018; 120: 709-723. https://doi.org/10.1016/j.fct.2018.08.031.

25. Jackson JK, Patterson AJ, MacDonald-Wicks LK, Forder PM, Blekkenhorst LC, Bondonno CP, et al. Vegetable nitrate intakes are associated with reduced self-reported cardiovascular-related complications within a representative sample of middle-aged Australian women, prospectively followed up for 15 years. Nutrients 2019; 11(2): E240. https://doi.org/10.3390/nu11020240.

26. Wallace TC, Bailey RL, Blumberg JB, Burton-Freeman B, Chen CO, Crowe-White KM, et al. Fruits, vegetables, and health: A comprehensive narrative, umbrella review of the science and recommendations for enhanced public policy to improve intake. Crit Rev Food Sci Nutr 2020; 60(13): 2174-2211. https://doi.org/10.1080/10408398.2019.1632258.

27. Stea TH, Nordheim O, Bere E, Stornes P, Eikemo TA. Fruit and vegetable consumption in Europe according to gender, educational attainment and regional affiliation - A cross-sectional study in 21 European countries. PLoS One 2020; 15(5): e0232521. https://doi.org/10.1371/journal.pone.0232521.

28. Blekkenhorst LC, Lewis JR, Prince RL, Devine A, Bondonno NP, Bondonno $\mathrm{CP}$, et al. Nitrate-rich vegetables do not lower blood pressure in individuals with mildly elevated blood pressure: A 4-wk randomized controlled crossover trial. Am J Clin Nutr 2018; 107(6): 894-908. https://doi.org/10.1093/ajcn/nqy061.

29. Larsson K, Darnerud PO, llbäck NG, Merino L. Estimated dietary intake of nitrite and nitrate in Swedish children. Food Addit Contam Part A Chem Anal Control Expo Risk Assess 2011; 28(5): 659-666. https://doi.org/10.1080/19440049.2011.555842.

30. Fossen Johnson S. Methemoglobinemia: Infants at risk. Curr Probl Pediatr Adolesc Health Care. 2019; 49(3): 57-67. https://doi.org/10.1016/i.cppeds.2019.03.002.

\section{Authors:}

Olga G. Bogdanova - MD, PhD, Senior Researcher, Laboratory of Environmental and Hygienic Research, East-Siberian Institute of Medical and Ecological Research, Angarsk, Russia, https://orcid.org/0000-00022358-2280.

Natalia V. Efimova - MD, DSc, Professor, Lead Researcher, Laboratory of Environmental and Hygienic Research, East-Siberian Institute of Medical and Ecological Research, Angarsk, Russia, https://orcid.org/0000-00017218-2147.

Inna Yu. Tarmaeva - MD, DSc, Professor, Secretary of the Academic Council, Lead Researcher, Laboratory of Age-Related Nutritional Science, Federal Research Centre of Nutrition and Biotechnology, Moscow, Russia, https://orcid.org/0000-0001-7791-1222. 